\title{
Company financial performance: Does board size matter? Case of the EUROSTOXX50 index
}

\author{
Rendimiento financiero de la empresa: iImporta \\ el tamaño del consejo de administración? Caso del \\ índice EUROSTOXX50
}

\author{
Mercedes RodríGuez-FernándeZ ${ }^{1}$ \\ Universidad de Málaga (España)
}

Recibido el 19 de mayo de 2014, aceptado el 21 de octubre de 2014

$\mathrm{N}^{\mathrm{o}}$ de clasificación JEL: M21, G34

DOI: $10.5295 / \mathrm{cdg} .140474 \mathrm{mr}$

\begin{abstract}
:
This study analyzes the relationship between board size and economic-financial performance in a sample of European firms that constitute the EUROSTOXX50 Index. Based on previous literature, resource dependency and agency theories, and considering regulation developed by the OECD and European Union on the normative of corporate governance for each country in the sample, the authors propose the hypotheses of both positive linear and quadratic relationships between the researched parameters. Using ROA as a benchmark of financial performance and the number of members of the board as measurement of the board size, two OLS estimations are performed. To confirm the robustness of the results the empirical study is tested with two other similar financial ratios, ROE and Tobin's $Q$. Due to the absence of significant results, an additional factor, firm size, is employed in order to check if it affects firm performance. Delving further into the nature of this relationship, it is revealed that there exists a strong and negative relation between firm size and financial performance. Consequently, it can be asseverated that the generic recommendation "one size fits all" cannot be applied in this case; which conforms to the Recommendations of the European Union that dissuade using generic models for all countries.
\end{abstract}

Keywords:

Corporate governance, board size, ROA, ROE, Tobin's Q, EUROSTOXX50 Index.

\section{Resumen:}

Este estudio analiza la relación entre el tamaño del consejo de administración y el rendimiento económicofinanciero de una muestra de empresas europeas que componen el EUROSTOXX50. Revisando trabajos anteriores en la materia y teniendo en cuenta además de la teoría de dependencia de recursos y la teoría de la agencia, la regulación que se ha desarrollado desde la OCDE, la Unión Europea, y la relativa al gobierno corporativo de cada país de la muestra, los autores proponen la existencia de una relación positiva entre las dos ideas investigadas. Tomando en consideración el número de consejeros y varias medidas del rendimiento económico-financiero (ROA, ROE y $Q$ de Tobin), se realiza la estimación estadística y ante la ausencia de resultados significativos se infiere la existencia de factores adicionales, como el tamaño empresarial, influyentes en la relación. Indagando

\footnotetext{
${ }^{1}$ Departamento Economía y Administración de Empresas, Facultad de Estudios Sociales y del Trabajo, Ampliación Campus de Teatinos, 29071 Málaga (Spain).mmrodriguez@uma.es
} 
en este otro factor se llega a una importante conclusión: el hecho de que existe una fuerte y negativa relación entre el tamaño de la compañia y el correspondiente rendimiento financiero. Por tanto, se puede aseverar que la recomendación genérica "un tamaño vale para todo" en este estudio no es aplicable, lo que, por otro lado, va en consonancia con las recomendaciones de la Unión Europea que desaconsejan modelos genéricos para todos los países integrantes.

\section{Palabras clave:}

Gobierno corporativo, tamaño del consejo de administración, ROA, ROE, Q de Tobin, índice EUROSTOXX 50. 


\section{INTRODUCTION}

The objective of the present work is to analyze if there is a relationship between the size of the boards of directors and the respective financial performance of firms. It also aims to find the role that best defines this relationship. We analyzed a sample of European companies that make up the EUROSTOXX50 in 2012, taking corporate governance and financial data for the year 2010 .

The interest of the work lies in the possibility of investigating one of the characteristics of the board of directors that supposedly has a direct impact on the value of financial performance. The number of board members is a fundamental aspect in the development of the functions that has been entrusted to the board of directors; thus, the direction taken by the firms is a consequence of how the functions assigned to this body are carried out.

It is our belief that Europe's economic reality demands more and more studies of this type, which investigate the governance structures of companies that have an important role in our global economy; and, how these internal forms of governance can be the cause of changes in the levels of economic profitability achieved. The size of the board has traditionally been a widely debated issue in the financial press, focusing on both its increase and decrease. News constantly appearing on changes in the boards of the large European companies has become a controversial issue. While more members on the board mean a greater contribution of experience and contacts favorable to the company, the associated cost, in terms of remuneration to the trustees, is a factor not to be taken lightly.

Considering the deepening link between the size of the board and the profitability of the firm, it is appropriate to outline, through the review of the different guidelines and principles relating to corporate governance of the countries included in the sample of firms (Germany, Belgium, Spain, France, Italy, Netherlands and Luxembourg), the standpoint of the various European bodies. Hence, the position taken in regards to the size of the board, and, in the mechanisms established by the board of the companies in the sample is analyzed in order to establish what is considered an appropriate size.

The work discusses both the OECD principles of corporate governance (2004) and the European regulations on corporate governance, and attempts to uncover the causes that have led to the proliferation of codes of good governance in the member countries of the European Union and the OECD. Likewise, the codes of the countries in the sample are reviewed, with the aim, in reference to board size, of extrapolating the recommendation in each of these. In the analysis we have used the original corporate governance and financial data of the companies in the sample for the year 2010. Via both the linear and quadratic regression statistical models, we have posited the equations that relate both objects of research.

The research was divided into several sections. First, a review of the literature and presentation of the theories that provide the foundations for the basic assumption of the study is performed. Next, we introduce the most relevant works in this area and discuss the guidelines set by the OECD and the European Union, as well as the codes of good governance of the countries in the sample, with regard to corporate governance. In the third section we expose the assumptions of the work that gave rise to the formulation of the econometric model used in our analysis; this, along with the presentation of the display and the data used, is listed in the subsequent part. In the fifth section, we proceed to the 
empirical application of the defined model and explain the results of that analysis. Finally, the sixth segment presents the findings of the study and outlines suggestions for future lines of investigation.

\section{REVIEW OF THE LITERATURE: THEORETICAL FRAMEWORK AND EM- PIRICAL EVIDENCE}

The question of whether a greater number of trustees bring about better financial results to the companies depends in a positive sense on the theory of resource dependency; and, some authors analyze the boards of directors (Barroso et al. 2011) based on this theory. From this perspective the board members are the nexus between the company and the resources it needs to maximize value (Pfeffer 1973; Pfeffer and Salancik 1978); in this way realizing that a larger number of members in the council entail greater possibilities for obtaining resources. The council represents in itself a fundamental resource for the company by its ability to link with the outside (Palmer and Barber 2001). Facing competition, the council can bring forth an advantage which is difficult to imitate (Barney 1991; Grant 1991).

Considering that the theory of agency (Jensen and Meckling 1976; Fama 1980; Fama and Jensen 1983) supports any mechanism that solves the conflict of interest between managers and owners, the board of directors is seen as a good tool to align their respective competing interests. We can therefore deduce that councils with a large number of members could exercise better control on managers than those with a smaller number (Freeman 1984; Donaldson and Preston 1995; Donaldson 1999; Frooman 1999).

A linear relationship between size and financial performance should not be assumed in spite of the fact that both theories - agency and resource dependency - show a positive relationship between the two concepts. The size of the council must provide a balance between the advantages and disadvantages of an increase of a new member to the council. The main benefit derived from the incorporation of additional members to the council, in addition to those already identified in the two theories, consists of the capacity and experience that the new member can contribute to the body. The most notable disadvantages stem from difficulties in communication, coordination, and the delays that occur in the decision-making process. Possible counterparts to large boards are 1) the asymmetry in the information held by the president of the board and the director of the company (Conyon and Peck 1998), and 2) a tendency to make new appointments instead of replacements, as is usually done in councils of a more limited size (Mak and Kusnadi 2005). Thus, some researchers have focused their research on inquiring as to what is the optimum number of trustees (Fernández et al. 1998; De Andrés and Vallelado 2008).

Corporate governance involves one more element to add to the regulatory framework under which firms must operate. To improve its functioning, codes of good practices have arisen, more commonly known as Codes for Good Governance, which focus on the aspects of operation and the structures of the councils. All the countries that make up the sample (Germany, Belgium, Spain, France, Italy, Netherlands and Luxembourg) have developed codes of good governance following both the recommendations of the OECD and those of the European Union. The principles of corporate governance promulgated by the OECD 
(2004) established a guideline for all listed companies: for the development of non-binding standards that, while respecting existing national law, promote good practices in corporate governance. The principles adopted in the year 1999 focused mainly on the problem of separating ownership and control; but also dealt with other aspects, such as the shareholding structure.

Furthermore, the European Union encourages the Member States to adopt the principles of the OECD; and, in its recommendations for corporate governance (EU 2012) indicates that countries must establish their own rules - hence are not obliged to follow a single pattern: "one size fits all" - adapted to company specifics (Seidl et al. 2013). It is appropriate to set a limit to the number of members that compose the board of directors in order to promote the quality of this body.

After analyzing the various codes developed in the nations of our sample study, we conclude that in only a few countries are indications clear on this aspect. A size of between 5 and 15 members is recommended only in the case of Spain, and a maximum limit is given only for the case of Luxembourg; the remaining codes do not set any references. Nonetheless, 17 listed Spanish companies belonging to IBEX35 have boards of more than 15 directors. These data suggest that half the companies comprising the IBEX 35 have very large boards - a situation that impairs the efficacy of this governing body and reduces the cohesion, involvement and accountability of its members (Gutierrez and Surroca 2012). Steen (2006) points out in his work that out of a total of 52 analyzed codes of good governance, in only $15 \%$ are limitations set on the size of the board.

Table 1

Relationship on good governance codes of countries in the sample, year of publication, year of last review and recommendation on size of the board

\begin{tabular}{|c|c|c|c|c|}
\hline Country & Existing Code Designation & $\begin{array}{c}\text { First } \\
\text { edition }\end{array}$ & $\begin{array}{c}\text { Last } \\
\text { revision }\end{array}$ & $\begin{array}{l}\text { Recommended } \\
\text { Board Size }\end{array}$ \\
\hline Belgium & Belgian Corporate Governance Code & 1998 & 2009 & Unspecified \\
\hline France & $\begin{array}{l}\text { Recommendations on corporate gover- } \\
\text { nance }\end{array}$ & 1995 & 2011 & Unspecified \\
\hline Germany & German Corporate Governance Code & 1998 & 2012 & Unspecified \\
\hline Italy & Italian Corporate Governance Code & 1999 & 2011 & Unspecified \\
\hline Luxembourg & $\begin{array}{c}\text { The Ten Principles of Corporate } \\
\text { Governance of the Luxembourg Stock } \\
\text { Exchange }\end{array}$ & 2003 & 2009 & Maximum 16 \\
\hline Netherlands & Dutch Corporate Governance Code & 1997 & 2008 & Unspecified \\
\hline Spain & $\begin{array}{l}\text { Unified Code of Good Governance: } \\
\text { Report Conthe }\end{array}$ & 1998 & 2006 & From 5 to 15 \\
\hline
\end{tabular}

Source: Own elaboration. 
The first codes of good governance emerged in the nineteen nineties, but on the benefits of their application some doubts exist (Soltani and Maupetit 2013). The fault that some scholars find lies in the lack of empirical evidence to support the contained recommendations (Steen 2006). For other authors (Cuervo 2002), the main stumbling block revolves around the lack of applicability; as such, they are in favor of promoting market control mechanisms, as opposed to merely enhancing governance codes.

Criticism is directed at the European countries, where the codes lack legal force and systems are geared towards large shareholders. In contrast, countries with an Anglo-American tradition develop market control systems, and codes stand as laws - these countries possess legal systems where the laws are drafted in Parliament. The Anglo-American countries, unlike the Europeans, uphold systems that differ in the fundamental aspect that codes have the attribute of law that companies must abide by (Goergen et al. 2008).

Bearing in mind that this study takes a sample of European countries, we set out to determine whether the recommendations on size, as established in the codes, are correct or not. Nevertheless, we must question if boards with a higher number of directors have a direct and positive impact on financial performance.

Studies to date, including those where no relationship has been found to exist at all, have produced mixed results. There are studies in samples of Eurozone countries that have found a positive relationship between size and profitability: Alves and Mendes (2004) in Portugal; Barroso et al. (2009, 2010); Fernández et al. (1998); and Rodríguez Fernández et al. (2013) in Spain. This has also been the case in international samples, or from countries outside Europe: Dalton et al. (1999) and Larmou and Vafeas (2010) in international companies; Jackling and Johl (2009) and Raja and Kumar (2008) in India; Kiel and Nicholson (2003) in Australia; McIntyre et al. (2007) in Canada; Reddy et al. (2010) in New Zealand, and finally, Uadiale (2010) in Nigeria.

The negative relationship has been manifested in the studies on European countries by Drakos and Bekiris (2010) in Greece; Guest (2009) in England and O'Conell and Cramer (2010) in Ireland. Also in studies by Daraghma and Alsinawi (2010) in Palestine; De Andres et al. (2005) in North America and Eastern Europe; Dey and Chauchan (2009) and Kota and Tomar (2010) in India; and Dowell et al. (2011) in the international arena.

The lack of relationship has been presented in the studies of Crespi (2010) in Spain; Di Pietra et al. (2008) in Italy; Beiner et al. (2004) in Switzerland, Lehn et al. (2009) in the USA; Yammeesri and Herath (2010) in Thailand and finally, Dalton et al. (1998) and Gill et al. (2009) in international samples.

Moreover, multiple investigations have attempted to calculate the optimal number of members that must compose the board of directors in order to maximize company financial performance. Guest (2009) analyzed a sample of English companies between the years 1981 and 2002 and concluded that in boards with greater than 9 members financial yields deteriorate. In the study conducted by De Andres and Vallelado (2008) on a sample of 69 banks in six countries of Europe and North America the optimal size is found to be 19; and, Fernández et al. (1998) in a sample analyzed in Spain during the year 1993 obtains a similar size, between 17 and 18 . 


\section{HYPOTHESES FORMULATION}

For the formulation of the hypotheses we will use as framework the work of Rodríguez Fernández et al. (2013) where the authors compiled a comprehensive series of studies that related various structural characteristics of the board with company financial performance. Specifically, for board size they identified 12 studies where the relationship was positive, 8 where it was negative, and 5 where no relationship existed. Table 2 shows these relations.

Table 2

Studies, characteristics, and board size

\begin{tabular}{|c|c|c|c|c|c|}
\hline Study & Country & $\begin{array}{l}\text { Board } \\
\text { size }\end{array}$ & Theories & $\begin{array}{l}\text { Listed } \\
\text { Y=Yes } \\
\text { N=No }\end{array}$ & $\begin{array}{c}\text { Profitability } \\
\text { Measurement }\end{array}$ \\
\hline $\begin{array}{l}\text { Alves and } \\
\text { Mendes } 2004\end{array}$ & Portugal & + & - & $\mathrm{Y}$ & ROA \\
\hline $\begin{array}{l}\text { Ameer et al. } \\
2010\end{array}$ & Malaysia & & $\begin{array}{l}\text { Agency, Stew- } \\
\text { ardship and } \\
\text { Resource depen- } \\
\text { dence theory }\end{array}$ & $\mathrm{Y}$ & Tobin's Q \\
\hline $\begin{array}{l}\text { Baliga et al. } \\
1996\end{array}$ & USA & & Agency theory & $\mathrm{N}$ & ROA, ROE \\
\hline $\begin{array}{l}\text { Barroso et al. } \\
2009\end{array}$ & Spain & + & $\begin{array}{l}\text { Agency, Steward- } \\
\text { ship, Resource } \\
\text { dependence } \\
\text { theories }\end{array}$ & $\mathrm{Y}$ & $\begin{array}{l}\text { Economic profit- } \\
\text { ability as } \\
\text { a control vari- } \\
\text { able }\end{array}$ \\
\hline $\begin{array}{l}\text { Barroso et al. } \\
2011\end{array}$ & Spain & + & $\begin{array}{l}\text { Resource depen- } \\
\text { dence theory }\end{array}$ & Y & - \\
\hline $\begin{array}{l}\text { Bhagat and } \\
\text { Black } 2002\end{array}$ & USA & & Empirical study & $\mathrm{N}$ & ROA, Tobin's Q \\
\hline $\begin{array}{l}\text { Brick and } \\
\text { Chindamba- } \\
\text { ran } 2010\end{array}$ & USA & & Empirical study & $\mathrm{N}$ & ROA, Tobin's Q \\
\hline Crespi 2010 & Spain & Without Relation & - & $\mathrm{Y}$ & $\begin{array}{l}\text { ROA, ROE, } \\
\text { Tobin's Q }\end{array}$ \\
\hline $\begin{array}{l}\text { Dalton et al. } \\
1998\end{array}$ & $\begin{array}{c}\text { Internatio- } \\
\text { nal }\end{array}$ & & $\begin{array}{l}\text { Agency and } \\
\text { Stewardship } \\
\text { theories }\end{array}$ & $\mathrm{N}$ & $\begin{array}{l}\text { ROA, ROE, } \\
\text { Tobin's Q }\end{array}$ \\
\hline $\begin{array}{l}\text { Dalton et al. } \\
1999\end{array}$ & $\begin{array}{c}\text { Internatio- } \\
\text { nal }\end{array}$ & + & $\begin{array}{l}\text { Agency, Steward- } \\
\text { ship, Resource } \\
\text { dependence } \\
\text { theories }\end{array}$ & $\mathrm{N}$ & $\begin{array}{l}\text { ROA, ROE, } \\
\text { Tobin's Q }\end{array}$ \\
\hline $\begin{array}{l}\text { Daraghma } \\
\text { and Alsinawi } \\
2010\end{array}$ & Palestine & - & - & $\mathrm{Y}$ & $\begin{array}{l}\text { Return on reve- } \\
\text { nues or sales }\end{array}$ \\
\hline
\end{tabular}


Western

De Andrés et al. 2005

Europe and Northamerica

Dey and

Chauchan 2009

Di Pietra et al. 2008

Dowell et al. 2011

Drakos and

Bekiris 2010

Ehikioya 2009

Elsayed 2007

Fernandez et al. 1998

Ferris et al. 2003

Fich and

Shivdasani

2006

Gill et al. 2009

Guest 2009

Hu et al. 2010

Jackling and

Johl 2009

Judge et al.

2003

Russia

Kaczmarek et al. 2011

UK

Kiel and

Nicholson 2003

Kota and Tomar 2010

Internatio-

nal

Greece

Nigeria

Egypt

Spain

USA

USA

International

United

Kingdom

China

India

rosia

Australia

India
Agency theory

Agency theory

Italy WithoutRelation

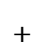

Without Relation

Agency theory

Agency and

Resource dependence theories

Agency theory and Institutional Perspectives

Agency theory and Social identity theory

Resource dependence theory

Agency, Stewardship and Managerial hegemony theories
$\mathrm{N}$

Y

$\mathrm{Y}$

Y

ROA, Tobin's Q

M/B , ROA, Version of Tobin's $\mathrm{Q}$

Market Value

Added and

Tobin's Q

M/B

Measure of financial distress

ROA, Tobin's Q

ROA, ROE,

Tobin's Q

Tobin's Q, ROA

Tobin's Q

M/B

M/B, ROA

ROA, ROE,

Tobin's Q

ROA, Tobin's Q

Tobin's Q

ROA, Tobin's Q

Financial Profitability

Tobin's Q

Y

Y

Tobin's Q 


\begin{tabular}{|c|c|c|c|c|c|}
\hline $\begin{array}{l}\text { Larmou and } \\
\text { Vafeas } 2010\end{array}$ & $\begin{array}{c}\text { Internatio- } \\
\text { nal }\end{array}$ & + & - & $\mathrm{N}$ & $\begin{array}{c}\text { before } \\
\text { depreciation } \\
\text { divided by total } \\
\text { assets }\end{array}$ \\
\hline $\begin{array}{l}\text { Lehn et al. } \\
2009\end{array}$ & USA & $\begin{array}{l}\text { Without } \\
\text { Relation }\end{array}$ & Agency theory & $\mathrm{Y}$ & $\mathrm{M} / \mathrm{B}$ \\
\hline $\begin{array}{l}\text { Lin et al. } \\
2009\end{array}$ & China & & Agency theory & $\mathrm{Y}$ & Sales revenue \\
\hline $\begin{array}{l}\text { McIntyre et } \\
\text { al. } 2007\end{array}$ & Canada & + & $\begin{array}{c}\text { Agency and } \\
\text { Behavioural } \\
\text { theories }\end{array}$ & $\mathrm{Y}$ & $\begin{array}{c}\text { ROA, Tobin's Q, } \\
\text { EVA }\end{array}$ \\
\hline $\begin{array}{l}\text { Miwa and } \\
\text { Ramseyer } \\
2005\end{array}$ & Japan & & Reformist theory & $\mathrm{Y}$ & $\begin{array}{c}\text { Tobin's Q and } \\
\text { ROI }\end{array}$ \\
\hline Mura 2007 & $\begin{array}{l}\text { United } \\
\text { Kingdom }\end{array}$ & & - & $\mathrm{Y}$ & Tobin's Q \\
\hline $\begin{array}{l}\text { O’Connell }^{\prime} \text { and Cramer } \\
\text { and } \\
2010\end{array}$ & Ireland & - & Agency theory & $\mathrm{Y}$ & $\begin{array}{l}\text { RET and FI- } \\
\text { NANCIAL Q }\end{array}$ \\
\hline $\begin{array}{l}\text { Raja and } \\
\text { Kumar } 2008\end{array}$ & India & + & Agency theory & $\mathrm{Y}$ & Tobin's Q \\
\hline $\begin{array}{l}\text { Reddy et al. } \\
2010\end{array}$ & $\begin{array}{c}\text { New Zea- } \\
\text { land }\end{array}$ & + & Agency theory & $\mathrm{Y}$ & $\begin{array}{c}\text { ROA, Tobin's } \mathrm{Q}, \\
\text { M/B }\end{array}$ \\
\hline $\begin{array}{l}\text { Schmid and } \\
\text { Zimmermann } \\
2008\end{array}$ & Switzerland & & Agency theory & $\mathrm{Y}$ & Tobin's Q \\
\hline $\begin{array}{l}\text { Stanwick and } \\
\text { Stanwick } \\
2010\end{array}$ & Canada & & $\begin{array}{l}\text { Agency and } \\
\text { Resource depen- } \\
\text { dence theories }\end{array}$ & $\mathrm{N}$ & $\begin{array}{c}\text { Ratio of sales to } \\
\text { net income }\end{array}$ \\
\hline $\begin{array}{l}\text { Tin Yan Lam } \\
\text { and Shu Kam } \\
\text { Lee } 2008\end{array}$ & Hong-Kong & & $\begin{array}{l}\text { Agency and } \\
\text { Stewardship } \\
\text { theories }\end{array}$ & $\mathrm{Y}$ & $\begin{array}{l}\text { ROA, ROE, } \\
\text { ROCE,M/B }\end{array}$ \\
\hline Uadiale 2010 & Nigeria & + & Agency theory & $\mathrm{Y}$ & ROE, ROCE \\
\hline $\begin{array}{l}\text { Yammeesri } \\
\text { and Herath } \\
2010\end{array}$ & Thailand & $\begin{array}{l}\text { Without } \\
\text { Relation }\end{array}$ & Agency theory & $\mathrm{Y}$ & Tobin's Q \\
\hline
\end{tabular}

Source: Own elaboration based on Rodriguez Fernandez et al. (2013)

In spite of the fact that both the theory of resource dependency and the theory of agency indicate a positive relationship between financial performance and board size, a lack of empirical homogeneity has been demonstrated. Taking into account 1) that the council should seek a balance between the advantages and disadvantages derived from the incorporation of new members, 2) that investigations have found evidence of the quadratic nature of the 
relationship (Fernández et al. 1998; De Andres and Vallelado 2008), and 3) that the OECD, the European Union and a number of good governance codes explicitly refer to imposing a limit on the number of directors - whereas in others, at the very least, the recommendation is given to monitor this aspect so as to not create problems of coordination, communication and dilatoriness in the decision-making process caused by an excess number of members in the council - we expect to find both positive and quadratic relationships in the analyses to be performed. Henceforth, we establish the following base hypotheses as:

Hypothesis 1: Company financial performance is positively related to the size of the board of directors.

Hypothesis 2: Above a given optimal number of directors in the governing council, company financial performance is adversely affected.

\section{METHODOLOGY}

\subsection{Sample and data collection}

The initial sample of the study is composed of those companies that made up the EUROSTOXX50 index in October 2012; they have been identified through the http://www. stoxx.com page. The EUROSTOXX50 index covers 12 countries in the euro zone, all members of the OECD (Germany, Austria, Belgium, Spain, Finland, France, Greece, Netherlands, Ireland, Italy, Luxembourg, Portugal), and includes the 50 leading companies from different sectors. On the date of the data query (accessed October 4, 2012) there was no company from either Austria, Greece or Portugal.

Financial data have been obtained from the database http://money.msn.com/ and http:// es.finance.yahoo.com/; and thereafter checked with Amadeus. The corporate data have been obtained from the SSBI reports (Spencer Stuart Board Index) ${ }^{2}$ as well as from the annual reports on corporate governance published by the companies located on the web pages of the companies themselves, or from the respective stock exchanges. The financial data, as well as the corporate governance data, correspond to the year 2010 .

The final sample of data is made up of 47 companies from seven countries: Germany, Belgium, Spain, France, Italy, Netherlands, and Luxembourg. Three companies included in the EUROSTOXX50 were left out of the study due to lack of financial data (one each from Germany and Finland, and another from Ireland). The index comprises the Eurozone's main super sector leaders, hence we deem the sample size adequate for our purpose.

2 Reports obtained in the page http://www.spencerstuart.com 


\subsection{Regression Model}

Based on resource dependency theory and agency theory, and following the model suggested by De Andres and Vallelado (2008), we will analyze the following regression model:

Financial Performance $=\alpha+\beta 1$. N_CONSEJEROS $+\beta 2$. N_CONSEJEROS $^{2}+$ $\beta 3$. LNASSETS $+\beta 4$.VARIABLES_CONTROL $+€$

Financial performance is the dependent variable and is measured through the ROA (return on assets) ratio, which is calculated as the quotient between the operating profit before depreciation, amortizations, provisions, and total assets. To analyze the robustness of the model we will make use of two additional ratios, 1) ROE (return on equity), which is calculated as the quotient between the operating profit before depreciation, amortizations, provisions, and stockholders equity, and 2) Tobin's Q ratio, the result of dividing company market value by its book value. These ratios were selected in accordance with previous analysis carried out by other authors in this field (Dalton et al. 1999; Alves and Mendes 2004; De Andres and Vallelado 2008; Guest 2009; Jackling and Johl 2009; Crespi 2010).

The independent variable that represents the size of the council is N_CONSEJEROS, the number of members comprising the board of directors. The other explanatory variable that has been included is LNASSETS, which represents the size of the firm and is calculated as the natural logarithm of total assets. Some authors (Guest 2009) have identified that financial performance is positively related with company size and include it as a control variable in the analysis between financial performance and size of the company. In addition, we include other control variables for sector, type of council (single or dual), and the group to which the council belongs - classified according to the observed size (small councils, fewer than 10 members; medium councils, 10 to 18 members; and large councils, greater than 18). The latter variables have been included by taking into account the observed variance of sizes and in line with the investigation of De Andres et al. (2005), who proposed a similar variable.

For the study of the hypotheses, two multivariate regression models are suggested: one corresponds to a linear model and the other to a quadratic model. The linear model serves to test hypothesis 1 and is represented by the equation:

Financial Performance $=\alpha+\beta 1$. N_CONSEJEROS $+\beta 2$. LNASSETS + $\beta 3$. VARIABLES_CONTROL $+€$

The quadratic model tests hypothesis 2 and is represented by:

Financial Performance $=\alpha+\beta 1$. N_CONSEJEROS $+\beta 2$. N_CONSEJEROS ${ }^{2}+$ $\beta 3$. LNASSETS $+\beta 4$.VARIABLES_CONTROL $+€$

To carry out the statistical analysis we have run the econometric software EViews 5.0, widely used in empirical research.

\section{ANALYSIS OF DATA AND RESULTS OF THE EMPIRICAL STUDY}

The observations correspond to European companies from different nations. For later analysis, data must first be grouped by country. Table 3 , below, shows the number of companies by country, company average size of council by country, and the number of compa- 
nies in which the council is divided as a function of task: control and monitoring (executive board and supervisory board).

Table 3

Number of firms, average size of the council, and number of companies with dual council by countries

\begin{tabular}{lccc}
\hline Country & No. of companies & $\begin{array}{c}\text { Average size the } \\
\text { council }\end{array}$ & $\begin{array}{c}\text { Companies with dual } \\
\text { councils }\end{array}$ \\
\hline Belgium & 1 & 13.0 & 1 \\
France & 18 & 14.3 & 0 \\
Germany & 12 & 25.7 & 12 \\
Italy & 5 & 15.8 & 0 \\
Luxembourg & 1 & 9.0 & 0 \\
Netherlands & 4 & 13.0 & 3 \\
Spain & 6 & 14.7 & 0 \\
Total & 47 & 17.2 & 16 \\
\hline
\end{tabular}

Source: Own elaboration.

The average board is composed of 17.2 members; as shown in Table 3, only in Germany do boards of directors on average consist of more than 16 members. Smaller governing boards are the norm in Luxembourg and the Netherlands, whereas in countries such as France, Italy and Spain the average number of directors is in the 14 to 15 members range. Germany has the highest average size, just under 26 directors; noteworthy is that all German companies in the sample have dual boards. In addition to the German firms, one Belgian and three Dutch firms favor dual councils; however, in these two countries average board size is considerably less.

In the chart shown below we have tabulated the total number of companies for each council size. We observe that a council of 14 board members is the most common, followed by councils of 12 and 13 members. 
Figure 1

Total number of companies as a function of number of council board members

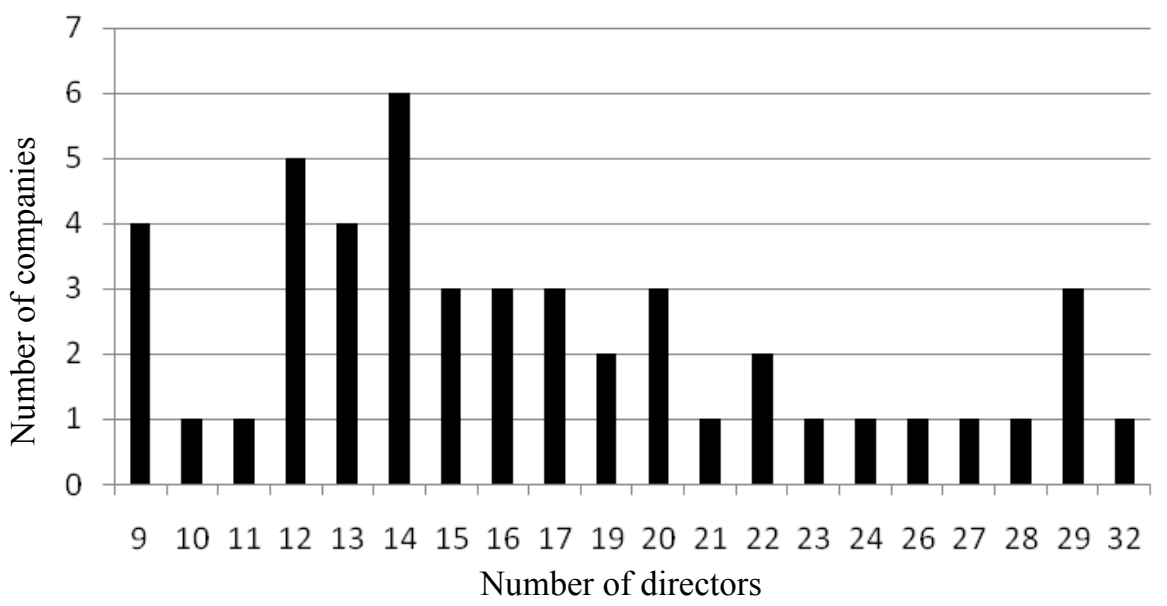

Source: Own elaboration.

The following table lists the total number of companies integrating each of the sectors; they are the Spanish equivalents of those indicated by EUROSTOXX50 (see Appendix).

Table 4

\section{Classification of companies by sector}

\begin{tabular}{lc}
\hline Sector & Number of companies \\
\hline Consumer Goods & 6 \\
Consumer Services & 4 \\
Financial Services and Real Estate & 5 \\
Banks & 8 \\
Construction, Manufacturing and Materials & 8 \\
Technology and Telecom. & 13 \\
Petroleum and Energy & 3 \\
Total & 47 \\
\hline
\end{tabular}

Source: Own elaboration.

The following table shows the total number of companies with dual boards, classified by country and by sector. 
Table 5

Number of companies with dual boards, classified by sector and by country

\begin{tabular}{lcccccc}
\hline & $\begin{array}{c}\text { Consumer } \\
\text { Goods }\end{array}$ & $\begin{array}{c}\text { Consumer } \\
\text { Services }\end{array}$ & $\begin{array}{c}\text { Financial } \\
\text { Services and } \\
\text { Real Estate }\end{array}$ & $\begin{array}{c}\text { Construction, } \\
\text { Manufacturing } \\
\text { and Materials }\end{array}$ & $\begin{array}{c}\text { Technolo- } \\
\text { gy and } \\
\text { Telecom. }\end{array}$ & Total \\
\hline $\begin{array}{l}\text { Belgium } \\
\text { France }\end{array}$ & & 1 & & & 1 \\
\hline $\begin{array}{l}\text { Germany } \\
\text { Italy }\end{array}$ & 2 & 1 & & & & 12 \\
$\begin{array}{l}\text { Luxembourg } \\
\text { Netherlands }\end{array}$ & & & & & & \\
Spain & 1 & & 2 & & 3 \\
\hline
\end{tabular}

Source: Own elaboration.

All German companies have dual boards, as do three of the Dutch and the sole Belgian company that integrate the sample. Withal, of the 16 companies that presented this particularity, almost half of them belong to the construction, industry and materials sector; the rest is divided between consumer goods and services, technology and telecommunications, financial services and real estate.

In Table 6 we have recorded the most significant values of the sample data.

Table 6

Descriptive statistics for the variables

\begin{tabular}{lccccc}
\hline & ROE2010 & ROA2010 & TOBINQ2010 & N_CONSEJEROS & LNASSETS2010 \\
\hline Media & 13.20 & 4.63 & 3.11 & 17.17 & 4.98 \\
Median & 11.60 & 3.60 & 2.15 & 15.00 & 4.82 \\
Maximum & 41.60 & 17.60 & 10.04 & 32.00 & 7.87 \\
Minimum & 2.10 & 0.10 & 0.82 & 9.00 & 1.92 \\
Standard & 8.02 & 4.15 & 2.18 & 6.15 & 1.46 \\
Deviation & 47 & 47 & 47 & 47 & 47 \\
Total & 47 & & & \\
\hline
\end{tabular}

Source: Own elaboration. 
The minimum and maximum values for the number of council members are 9 and 32 respectively.

As to correlations between variables, we underline that in view of the values shown in Table 7, the variable N_CONSEJEROS is negatively correlated with the three financial ratios that represent the dependent variable, ROA, ROE and Tobin's Q- ROA showing the greatest correlation. Variable LNASSETS2010 displays a negative correlation with the dependent variables.

Table 7

Pearson's correlations of variables in the regression model

\begin{tabular}{lccccc}
\hline & ROE2010 & ROA2010 & $\begin{array}{c}\text { TO- } \\
\text { BINQ2010 }\end{array}$ & $\begin{array}{c}\text { N_CONSEJE- } \\
\text { ROS }\end{array}$ & LNASSETS2010 \\
\hline ROE2010 & 1 & & & & \\
ROA2010 & 0.659 & 1 & & & \\
TOBINQ2010 & 0.681 & 0.788 & 1 & & \\
N_CONSEJEROS & $-0,134$ & $-0,288$ & $-0,177$ & 1 & 1 \\
LNASSETS2010 & $-0,479$ & $-0,752$ & $-0,729$ & 0.317 & \\
\hline
\end{tabular}

Source: Own elaboration.

Table 8

Results of the regression analysis

\begin{tabular}{lcccccc}
\hline \multicolumn{1}{c}{ Variables } & \multicolumn{2}{c}{ ROA2010 } & \multicolumn{2}{c}{ ROE2010 } & \multicolumn{2}{c}{ TOBINQ2010 } \\
& Analysis 1 & Analysis 2 & Analysis 1 & Analysis 2 & $\begin{array}{c}\text { Analy- } \\
\text { sis 1 }\end{array}$ & Analysis 2 \\
\hline$\alpha$ (constant) & 15,676 & 13,340 & 26,077 & 25,092 & 8,317 & 6,518 \\
N_CONSEJEROS & -0.037 & -0.249 & 0.0259 & 0,147 & 0.0212 & 0,241 \\
N_CONSEJE- & $(0,599)$ & $(0,572)$ & $(0,888)$ & $(0,898)$ & $(0,518)$ & $(0,375)$ \\
ROS $^{2}$ & & -0.007 & & -0.003 & & -0.006 \\
& & $(0,511)$ & & $(0,914)$ & & $(0,384)$ \\
LNASSETS2010 & -2.089 & -2.121 & -2.674 & -2.688 & -1.118 & -1.142 \\
& $(0.000) * * *$ & $(0.000) * * *$ & $(0.001)$ & $(0.0014)$ & $* .000)$ & $(0.003)$ \\
& & & $* * *$ & & & $* * *$ \\
$\mathrm{R}^{2}$ & & & & & & \\
Adjusted R & & & & & & \\
Durbin-Watson & 0,568 & 0,572 & 0,230 & 0,230 & 0,535 & 0.5445 \\
statistic & 0,548 & 0,542 & 0,195 & 0,177 & 0,514 & 0,513 \\
F-statistic & 2.04 & 2,071 & 2,301 & 2,300 & 1,905 & 1,965 \\
Prob.(F-statistic) & 28,900 & 19,168 & 6,577 & 4,290 & 25,342 & 17,150 \\
\hline
\end{tabular}

Source: Own elaboration. 
The values exhibited in the columns (Table 8) are the $\beta$ i coefficients that accompany the respective variables. Below, in brackets, we display the t statistic probability. The characters $*, * *$, and $* * *$ correspond, respectively, to $10 \%, 5 \%$ and $1 \%$ significance. The column "Analysis 1" presents the results for the linear model study (Hypothesis 1), whereas "Analysis 2" presents results for the quadratic model (Hypothesis 2).

The models are explanatory (prob. $\mathrm{F}<0.05$ ) in all cases; and, the model pertaining to the ROA (adjusted $\mathrm{R}^{2} 0.548$ in analysis 1 , and 0.542 in analysis 2) gives the best results. In none of the analysis have the variables N_CONSEJEROS and N_CONSEJEROS ${ }^{2}$ resulted significant; on the other hand, the variable reflecting the size of the firm (LNASSETS2010) shows significance. For this latter variable the relationship was negative in all cases $(\beta \mathrm{i}<$ $0)$. Hence, neither hypothesis 1 nor hypothesis 2 have been proven; although, we have found that the variable LNASSETS 2010 shows a strong negative relationship with financial performance.

After the completion of analysis 1 and 2 for the dependent variable ROA, variables ROE and Tobin's Q were analyzed; as no significance variance was found in the different measures of performance or firm value, the robustness of results was proved.

When including the control variables in the analysis (sector, type of council and classification by council size) no significant relationship appeared that would allow differences to be established - a consequence of these characteristics - between the companies.

After carrying out the White test, no heteroscedasticity ${ }^{3}$ has been found, except in analysis 2 for the Tobin's Q variable; in this latter case, we have computed White matrices and shown the results in Table 8 .

Other econometric problems that might have been present in the models, multicollinearity ${ }^{4}$ and autocorrelation ${ }^{5}$, were tested and discarded (Gujarati 2003). Multicollinearity was ruled- out as there was no evidence for presuming a relationship between the independent variables. Neither the statistical $F$ nor the adjusted $\mathrm{R}^{2}$ values are excessively high; furthermore, some of the independent variables are significant. As regards autocorrelation, in all cases the Durbin Watson statistic lies within the limits of non-autocorrelation, i.e. 1.5 $<$ DW $<2.5$ (Anatolyev 2003).

\section{FINAL CONCLUSIONS AND FUTURE RESEARCH}

In this work we have analyzed the size of the board of directors and its relationship with company financial performance. In the first scenario we proposed a positive relationship between these two variables, and in the second scenario considered its plausible quadratic relationship.

Despite the solid theoretical basis, resource dependency theory and agency theory, and prior empirical evidence to support the positive sign of the relationship, none can be asser-

\footnotetext{
${ }^{3}$ Heteroscedasticity occurs when the the principle of homoscedasticity is not met. Homoscedasticity is also known as homogeneity of variance.

${ }^{4}$ Multicollinearity refers to the existence of a linear relationship between the variables.

${ }^{5}$ Autocorrelation assumes that the variance associated with one given observation is not influenced by the variance associated with any other observation.
} 
ted. For EUROSTOXX50, which consists of large European firms, the size of the board is a parameter that can be deemed largely irrelevant. However, an important conclusion has been derived: a strong negative relationship exists between company size and its corresponding financial return; that is, given a constant number of board members, as company size increases financial performance decreases.

Nor can we recommend an optimum size, a consequence of the presumed inverted " $U$ " quadratic form association, in spite of the fact that other authors already pointed to this type of relationship and obtained optimal numbers of board members; and that some of the codes of good governance set ranges limiting the size of the Council.

A further conclusion drawn is that board size depends on additional factors, such as company specifics, and how no one-size-fits-all recommendation can be given that would benefit all councils. The recommendations of the EU are explicit in this regard and suggest the inadequacy of employing generic models; throughout Europe (with the exception of Spain and Luxembourg) national governments do not establish recommendations on the adequate size of the board of directors in large companies. Noteworthy, all German companies embrace board duality; a situation observed to a lesser degree in Dutch and Belgian firms. Certain authors question the similarities and recommendations of codes and, as a consequence of the consolidation of supporting empirical evidence, advocate for dialog between investors, companies and researchers to act as the driving force behind improvements in the codes of good governance.

Moreover, adapting corporate governance codes periodically, in response to changing social, economic, and financial conditions, guarantees that standards are continuously responsive to the vagaries of the marketplace. In this regard we advocate for national governments to coordinate the setting of codes with governance professionals, such as the International Corporate Governance Network (ICGN 2014), an organization which has gone a long way towards emphasizing the importance of proper corporate governance.

We have uncovered that a large variance exists in the size of the boards of directors in the different companies of the sample. However, we did not observe a common pattern that allowed us to suggest a relationship between council size and company sector, or between council size and firm performance.

Results have shown that increasing financial returns becomes an ever more difficult task as company size increases. Consequently, setting limits on its size can be deemed more important than targeting some ideal number of board members. Withal, our work clearly indicates an important duty of the board should consist in controlling company size; the focus should be on company size as opposed to board size, as our results demonstrate that a large company size depresses financial performance.

Hence, in light of our study and the lack of general recommendations on appropriate board size, we highlight the importance of considering company size as an additional factor to be taken into account when establishing codes of corporate governance; that is future recommendations on board size should be inextricably coupled with company size, given the strong linkage of the latter with financial performance. Furthermore, the main objective of the development of codes of good governance is not to enhance company financial returns (at least not in the short term) but rather to improve the control mechanisms in order to increase the confidence of the owners (investors) with respect to the decisions taken by 
the managers. From this vantage point, we advocate for the variable company size to be considered a constant over the long term.

Future research should strive to expand knowledge on the interplay between board size and firm size, and their dependency on financial results, across different geographic spheres of activity and influence - notwithstanding the aim to analyze jointly other variables of the board in a sample of greater size encompassing a longer time period; such avenues should include the exploration of the different effects of the economic crisis that began in 2008.

\section{ACKNOWLEDGEMENTS}

The author wishes to thank the reviewers for all the comments and suggestions made to the article.

\section{REFERENCES}

Alves, C. and Mendes, V., 2004. Corporate governance policy and company performance: The Experimenta sidebar case. Corporate Governance: An International Review, 12(3), 290-301.

Ameer, R., Ramli, F. and Zakaria, H., 2010. A new perspective on board composition and firm performance in an emerging market. Corporate Governance, 10(4), 647- 661.

Anatolyev, S., 2003. Durbin-watson statistic and random individual effects. Econometric Theory, 19(5), 882-883.

Baliga, B. R. and Moyer, C., 1996. CEO Duality and Firm Performance. What's the fuss? Strategic Management Journal, 17(1), 41-53.

Barney, J., 1991. Firm resources and sustained competitive advantage. Journal of Management, 17(1), 99-120.

Barroso Castro, C.; Domínguez de la Concha, M.; Vecino Gravel, J. and Villegas Periñan, M. M., 2009. Does the team leverage the board's decisions. Corporate Governance: An International Review, 17(6), 744-761.

Barroso Castro, C.; Villegas Periñan, M. M. and Perez-Calero, L., 2010. What are effective boards of directors? The effectiveness of the Council and the results of the company. Investigaciones Europeas de Dirección y Economía de la Empresa, 16(3), 107-126.

Barroso Castro, C.; Villegas Perinan, M. M. and Perez-Calero, L., 2011. Board influence on a firm's internationalization. Corporate Governance: An International Review, 19(4), 351-367.

Baliga, B. R. and Moyer, C., 1996. CEO Duality and Firm Performance. What's the fuss? Strategic Management Journal, 17(1), 41-53.

Beiner, S.; Drobetz, W.; Schmid, F. and Zimmermann, H., 2004. Board size is an independent corporate governance mechanism? Kyklos, 57 (3), 327-356.

Bhagat, S. and Black, B., 2002. The non-correlation between board independence and long-term firm performance. Journal of Corporation Law, 27(2), 231- 273. 
Brick, I. E. and Chidambaran, N.K., 2010. Board meetings, committee structure and firm value. Journal of Corporate Finance, 16 (4), 533-553.

CNMV, 1998. Report of the special commission for the study of an ethical code of the boards of directors of the companies (Olivencia Report). National Commission for the Securities Market.

CNMV, 2003. Report of the special commission for the promotion of transparency and security in the markets and listed companies (Aldama Report). National Commission for the Securities Market.

CNMV, 2006. Unified Code of corporate governance of listed companies (Conthe Code). National Commission for the Securities Market.

Conyon, M. J. and Peck, S. I., 1998. Board size and corporate performance: Evidence from European countries. The European Journal of Finance, 4 (3), 291-304.

Crespi, R., 2010. Observatory of corporate governance and transparency of information of companies quoted on the continuous market Spanish. Papers of the Foundation, 40. Foundation for Financial Studies.

Cuervo, A., 2002. Corporate governance mechanisms: A plea for less code of good governance and more market control. Corporate Governance: An International Review, 10 (2), 84-93.

Dalton, D. R., Daily, C. M., Ellstrand, A. E. and Johnson, J. L., 1998. Meta-analytic reviews of board composition, leadership structure, and financial performance. Strategic Management Journal, 19 (3), 269-290.

Dalton, D. R., Daily, C. M., Ellstrand, A. E. and Johnson, J. L., 1999. Number of directors and financial performance. A meta-analysis. Academy of Management Journal, 42(6), 674- 686.

Daraghma, Z. M. A. and Alsinawi, A. A., 2010. Board of Directors, Management Ownership and Capital Structure and Its Effect on Performance. The Case of Palestine Securities Exchange. International Journal of Business and Management, 5(11), 118- 127.

De Andres, P.; Azofra, V. and Lopez, F., 2005. Corporate boards in OECD countries: size, composition, functioning and effectiveness. Corporate Governance: An International Review, 13(2), 197- 210.

De Andres, P. and Vallelado, E., 2008. Corporate governance in banking: The role of the board of directors. Journal of Banking and Finance, 32, 2570-2580.

Dey, D. K. and Chauchan, Y. K., 2009. Board Composition and Performance in Indian firms: A Comparison. IUP Journal of Corporate Governance, 8(2), 7-19.

Di Pietra, R., Grambovas, C. A., Raonic, I. and Riccaboni, A., 2008. The effects of board size and 'busy' directors on the market value of Italian companies. IUP Journal of Management and Governance, 12(1), 73-91.

Donaldson, L., 1999. Making stakeholder theory whole. Academy of Management. The Academy of Management Review, 24 (2), 237-241.

Donaldson, T. and Preston, L. E., 1995. The Stakeholder theory of the corporation: Concepts, evidence and implications. Academy of Management Review, 20(1), 65-91.

Dowell, G. W. S., Shakell, M. B. and Stuart, N. V., 2011. Boards, CEOS, and surviving a Financial Crisis: Evidence from the Internet shakeout. Strategic Management Journal, 10 (32), 1025-1045.

Drakos, A. A. and Bekiris, F. V., 2010. Endogeneity and the relationship between board structure and firm performance: a simultaneous equation analysis for the Athens Stock Exchange. Managerial and Decision Economics, 31(6), 387-401. 
EC, 2005. Recommendations of the European Commission, February 15 th.

Ehikioya, B. I., 2009. Corporate governance structure and firm performance in developing economies: evidence from Nigeria. Corporate Governance, 9(3), 231-243.

Elsayed, K., 2007. Does CEO Duality Really Affect Corporate Performance? Corporate Governance: An International Review, 15(6), 1203-1214.

EU, 2012. Rules of corporate governance for the European companies (European Parliament Resolution of 29 March 2012, on a regulation of corporate governance for European companies 2011/2181(INI)). Obtained in http://www. europarl.europa.eu/sides/getDoc.do?type=TA\&reference=P7-TA-2012-0118\&language $=$ ES\&ring $=$ A7-2012-0051 (accessed 10/22/12).

Fama, E. F., 1980. Agency problems and the theory of the firm. Journal of Political Economy, 88(2), 288-307.

Fama E. F. and Jensen, M. C., 1983. Separation of ownership and control. Journal of Law and Economics, 26(2), 301-325.

Fernandez, A. I., Gomez-Anson, S. and Fernández-Méndez, C., 1998. The supervisory role of the board of directors on the managerial performance. Evidence for the case of Spain. Economic Research, 23(3), 501-516.

Ferris, S. P., Jagannathan, M. and Pritchard, A. C., 2003. Too Busy to Mind the Business? Monitoring by Directors with Multiple Board Appointments. The Journal of Finance, 58(3), 1087-1112.

Fich, E. M. and Shivdasani, A., 2006. Are Busy Boards Effective Monitors? The Journal of Finance, 61(2), 689-724.

Freeman, R. E., 1984. Strategic management: A stakeholder approach. Boston: Pitman.

Frooman, J., 1999. Stakeholder influence strategies. Academy of Management Review, 24, 191-205.

Gill, M. S., Vijay, T. S. and Jha, S., 2009. Corporate Governance Mechanisms and firm Performance: A Survey of Literature, Journal of IUP Corporate Governance, 8(1), 7-21.

Goergen, M., Manjon, M.C. and Renneboog, L., 2008. Is the German system of corporate governance converging towards the Anglo-American model? Journal of Management and Governance, 12, pp. 37-71. DOI: 10.1007/s10997-007-9040-7

Grant, R. M., 1991. The resource-based theory of competitive advantage: Implications for strategy formulation. California Management Review, 33(3), 114-135.

Guest, P. M., 2009. The impact of board size on firm performance: evidence from the UK. The European Journal of Finance, 15(4), 385-404.

Gujarati, D. N., 2003. Basic Econometric. Boston: Mcgraw-Hill.

Gutierrez, I. and Surroca, J., 2012. Revisiting corporate governance through the lens of the Spanish evidence. Journal of Management and Governance. DOI:10.1007/ s10997-012-9250-5

Hu, H. W., Tam, O. K. and Tan, M. G., 2010. Internal governance mechanisms and firm performance in China. Asia Pacific Journal of Management, 27(4), 727-749.

International Corporate Governance Network (ICGN), 2014. Consulted on www.icgn. org (accesed 4/14/2014)

Jackling, B. and Johl, S., 2009. Board structure and firm performance: Evidence from India's top companies. Corporate Governance: An International Review, 17(4), 492-509. 
Jensen, M. C. and Meckling, W. H., 1976. Theory of the firm: Managerial behavior, agency costs and ownership structure. Journal of Financial Economics, 3(4), 305-360.

Judge, W., Naoumova, Q. and Koutzevol, N., 2003. Corporate governance and firm performance in Russia: An empirical study. Journal of World Business, 38(4), 385-396.

Kaczmarek, S., Kimino, S. and Pye, A., 2011. Board task-related faultlines and firm performance: A decade of evidence. Corporate Governance: An International Review. DOI: 10.1111/j.1467-8683.2011.00895.x

Kiel, G. C. and Nicholson, G. J., 2003. Board Composition and Corporate Performance: how the Australian experience informs contrasting theories of corporate governance, Corporate Governance: An International Review, 11(3), pp. 189-205.

Kota, H. B. and Tomar, S., 2010. Corporate governance practices in Indian firms. Journal of Management and Organization, 16(2), 266-279.

Larmou, S. and Vafeas, N., 2010. The relation between board size and firm performance in firms with a history of poor operating performance. Journal of Management and Governance, 14(1), 61-85.

Lehn, K. M., Patro, S. and Zhao, M., 2009. Determinants of the size and composition of US Corporate Boards: 1935-2000. Financial Management, 38 (4), 747-780.

Lin, C.; Ma, Y. and Su, D., 2009. Corporate governance and firm efficiency: Evidence from China's publicly listed firms. Managerial and Decision Economics, 30(3), 193.

Mak, Y. T. and Kusnadi, Y., 2005. Size really matters: Further evidence on the negative relationship between board size and firm value. Pacific-Basin Finance Journal, 13 (3), 301-318.

McIntyre, M. L., Murphy, S. A. and Mitchell, P., 2007. The top team: examining board composition and firm performance. Corporate Governance, 7(5), 547-561.

Miwa, Y. and Ramseyer, J.M., 2005. Who appoints them, what do they do? Evidence on outside directors from Japan. Journal of Economics and Management Strategy, 14(2), 299-337.

Mura, R., 2007. Firm Performance: Do Non-Executive Directors Have Minds of their Own? Evidence from UK Panel Data. Financial Management, 36(3), 81-112.

OECD, 2004. OECD Principles of Corporate Governance. Obtained in http://www.oecd. org/daf/corporateaffairs/corporategovernanceprinciples/37191543.pdf, (accessed $22 / 10 / 12$ ).

O'Connell, V. and Cramer, N., 2010. The relationship between firm performance and board characteristics in Ireland. European Management Journal, 28(5), 387-399.

Palmer, D. and Barber, B. M., 2001. Challengers, elites and owning families: a social class theory of corporate acquisitions in the 1960s. Administrative Science Quarterly ,46(1), 87-120.

Pfeffer, J., 1973. Size, composition and function of hospital boards of directors: A study of organization-environment linkage. Administrative Science Quarterly, 18(3), 349-364.

Pfeffer, J. and Salancik, G. R., 1978. The external control of organizations: A Resource dependence perspective. New York: Harper \& Row.

Preston, L. E., 1998. Agents, stewards and stakeholder, Academy of Management. The Academy of Management Review, 23(1), 9-13.

Raja, J. and Kumar, A., 2008. SME entrepreneurship, firm performance, and corporate governance practices in Indian service firms. Journal of Services Research, 7(2), 99-113. 
Reddy, K., Locke, S. and Scrimgeour, F., 2010. The efficacy of principle-based corporate governance practices and firm financial performance: An empirical investigation. International Journal of Managerial Finance, 6(3), 190-219.

Rodríguez Fernández, M., Fernández Alonso, S. and Rodríguez Rodríguez, J., 2013. Estructura del consejo de administración y rendimiento de la empresa española cotizada. Revista Europea de Dirección y Economía de la Empresa, 22, 155-168.

Schmid, M. M. and Zimmermann, H., 2008. Should chairman and CEO be separated? Leadership structure and firm performance in Switzerland. Schmalenbach Business Review: $Z F B F, 60,182-204$.

Seidl, D., Sanderson, P. and Roberts, J., 2013. Applying the 'comply-or-explain' principle: discursive legitimacy tactics with regard to codes of corporate governance. Journal of Management \& Governance, 17, 791-826. DOI: 10.1007/s10997-011-9209-y

Soltani, B. and Maupetit, C., 2013. Importance of core values of ethics, integrity and accountability in the European corporate governance codes. Journal of Management Governance. DOI: 10.1007/s10997-013-9259-4

Spencer Stuart, 2011. Spain 2011.Index Spencer Stuart of Boards of Directors, 15th ed.

Stanwick, P. A. and Stanwick, S. D., 2010. The Relationship Between Corporate Governance and Financial Performance: An Empirical Study of Canadian Firms. The Business Review, Cambridge, 16(2), 35-41.

Steen T., 2006. The hidden meaning of codes: Corporate governance and investor rent seeking. European Business Organization Law Review, 7(4), 845-861.

Sternberg, E., 1997. The defects of stakeholder theory. Corporate Governance, 5(1), 3-10.

Tin Yan Lam, and Shu Kam Lee., 2008. CEO duality and firm performance: Evidence from Hong Kong. Corporate Governance, 8(3), 299-316.

Uadiale, O. M., 2010. The Impact of Board Structure on Corporate Financial Performance in Nigeria. International Journal of Business and Management, 5 (10), 155-166.

Yammeesri, J. and Herath, S. K., 2010. Board characteristics and corporate value: evidence from Thailand. Corporate Governance, 10 (3), 279-292. 


\section{APPENDIX. LIST OF COMPANIES INCLUDED IN THE EUROSTOXX50}

\begin{tabular}{|c|c|c|}
\hline Company name & Sector & Country code \\
\hline AIR LIQUIDE & Chemicals & FR \\
\hline ALLIANZ & Insurance & $\mathrm{DE}$ \\
\hline Anheuser-Busch INBEV & Food \& Beverages & $\mathrm{BE}$ \\
\hline ARCELORMITTAL & Basic Resources & LU \\
\hline ASML HLDG & Technology & NL \\
\hline ASSICURAZIONI GENERALI & Insurance & IT \\
\hline AXA & Insurance & FR \\
\hline BASF & Chemicals & $\mathrm{DE}$ \\
\hline BAYER & Chemicals & $\mathrm{DE}$ \\
\hline BCO BILBAO Vizcaya Argentaria & Banks & ES \\
\hline BCO SANTANDER & Banks & ES \\
\hline BMW & Automobiles \& Parts & $\mathrm{DE}$ \\
\hline BNP PARIBAS & Banks & FR \\
\hline CARREFOUR & Retail & FR \\
\hline $\mathrm{CRH} *$ & Construction \& Materials & IE \\
\hline DAIMLER * & Automobiles \& Parts & $\mathrm{DE}$ \\
\hline DANONE & Food \& Beverages & FR \\
\hline DEUTSCHE BANK & Banks & $\mathrm{DE}$ \\
\hline DEUTSCHE TELEKOM & Telecommunications & $\mathrm{DE}$ \\
\hline E. ON & Utilities & $\mathrm{DE}$ \\
\hline ENEL & Utilities & IT \\
\hline ENI & Oil \& Gas & IT \\
\hline ESSILOR INTERNATIONAL & Healthcare & FR \\
\hline FRANCE TELECOM & Telecommunications & FR \\
\hline GDF Suez & Utilities & FR \\
\hline GRP Société Générale & Banks & FR \\
\hline IBERDROLA & Utilities & ES \\
\hline INDITEX & Retail & ES \\
\hline ING GRP & Insurance & NL \\
\hline INTESA SANPAOLO & Banks & IT \\
\hline L'OREAL & Personal \& Household Goods & FR \\
\hline LVMH Moet Hennessy & Personal \& Household Goods & FR \\
\hline MUENCHENER RUECK & Insurance & $\mathrm{DE}$ \\
\hline
\end{tabular}




$\begin{array}{ccc}\text { NOKIA } * & \text { Technology } & \text { FI } \\ \text { PHILIPS ELECTRONICS } & \text { Industrial goods \& services } & \text { NL } \\ \text { REPSOL } & \text { Oil \& Gas } & \text { ES } \\ \text { RWE } & \text { Utilities } & \text { DE } \\ \text { SAINT GOBAIN } & \text { Construction \& Materials } & \text { FR } \\ \text { SANOFI } & \text { Healthcare } & \text { FR } \\ \text { SAP } & \text { Technology } & \text { DE } \\ \text { SCHNEIDER ELECTRIC } & \text { Industrial goods \& services } & \text { FR } \\ \text { SIEMENS } & \text { Industrial goods \& services } & \text { DE } \\ \text { TELEFONICA } & \text { Telecommunications } & \text { ES } \\ \text { TOTAL } & \text { Oil \& Gas } & \text { FR } \\ \text { Unibail RODAMCO- } & \text { Real Estate } & \text { FR } \\ \text { UNICREDIT } & \text { Banks } & \text { IT } \\ \text { Unilever NV } & \text { Food \& Beverages } & \text { NL } \\ \text { VINCI } & \text { Construction \& Materials } & \text { FR } \\ \text { VIVENDI } & \text { Media } & \text { FR } \\ \text { VOLKSWAGEN PREF } & \text { Automobiles \& Parts } & \text { DE }\end{array}$

* Companies that have not been included in the final sample for lack of data.

Source: Own elaboration with data of EUROSTOXX50 